\title{
Trend and dynamics of the COVID-19 pandemic in Latin America during the first wave
}

\section{Tendências e dinâmicas da COVID-19 na América Latina durante a primeira onda}

\author{
Renan Carrasco Cézar ${ }^{1}$. Mateus Lavor Lira ${ }^{1,2}$. Matheus Gama Nogueira ${ }^{1}$. Bruno Araújo de Freitas ${ }^{1}$. Lisandra \\ Serra Damasceno ${ }^{1}$. \\ 1 Universidade Federal do Ceará (UFC), Fortaleza, Ceará, Brasil. 2 Hospital Universitário Walter Cantídio (HUWC), Fortaleza, \\ Ceará, Brasil.
}

\begin{abstract}
Objective: The present study aimed to evaluate the trend and dynamics of COVID-19 in Latin America (LA). Methods: This ecological study was based on data published on the Pan American Health Organization and the World Health Organization websites. Information was collected in three periods: 05/10/2020 (Period A), 06/19/2020 (Period B), and 07/20/2020 (Period C). Descriptive analysis was performed. Results: In Period A, the number of confirmed cases of COVID-19 in LA had reached 284,521. In the second period, the number of cumulated cases was 1,958,180. In Period C, a total of 4,046,179 cases of COVID-19 had been notified. The highest prevalence and detection rates of COVID-19 in LA was reported in Chile, Panama, Peru, and Brazil. The mortality rate regarding new deaths in Period A was less than 60 deaths $/ 10^{6}$ habitants in all countries. However, in the second period, Ecuador (232 deaths $/ 10^{6} \mathrm{hab}$ ) presented the highest mortality rate. In Period C, the greatest rates were reported in Peru (297 deaths/10 hab) and Chile (248 deaths/10 $10^{6} \mathrm{hab}$ ). Brazil being accountable for the highest number of deaths in LA due to COVID-19. Conclusion: The trend and dynamics of COVID-19 spread in LA reveals the heterogeneous distribution and uncontrollability of the epidemic in several countries.
\end{abstract}

Keywords: COVID-19. Coronavirus disease 2019. Latin America. Mortality.

\section{RESUMO}

Objetivo: O presente estudo tem por objetivo avaliar as tendências e dinâmicas da COVID-19 na América Latina (AL). Métodos: Estudo ecológico baseado em dados publicados nos sites da Organização Panamericana da Saúde e Organização Mundial da Saúde. Os dados foram coletados em três períodos: 10/05/2020 (Período A), 19/06/2020 (Período B), e 20/07/2020 (Período C). Foi realizada análise descritiva. Resultados: No Período A, o número de casos confirmados de COVID-19 na AL registrados foram 284.521. no segundo período, o número de casos acumulados foi de 1.958.180, e no Período C foram notificados um total de 4.046.179 casos de COVID-19. As maiores prevalências e taxas de detecção foram reportadas no Chile, Panamá, Peru, e Brasil. A taxa de mortalidade de novos casos no Período A foi menor que 60 óbitos $/ 10^{6}$ habitantes (hab) em todos os países. Entretanto, no segundo período, o Equador apresentou a maior taxa de mortalidade (232 óbitos $/ 10^{6}$ hab), e no Período C, Peru (297 óbitos/10 6 hab) e Chile (248 óbitos/10 hab). O Brasil foi o país com o maior número de mortes por COVID-19 na AL. Conclusões: A dinâmica da COVID-19 na AL revelou uma distribuição heterogênea e incontrolável da epidemia em diversos países.

Palavras-chave: COVID-19. Doença por Coronavírus 2019. América Latina. Mortalidade.

Corresponding author: Lisandra Serra Damasceno, Universidade Federal do Ceará, Departamento de Saúde Comunitária, Rua Papi Junior, 1223, Rodolfo Teófilo, Fortaleza, Ceará, Brasil. CEP: 60430-235. Telefone: +55 85 3366-8044. E-mail: lisandra.damasceno@ufc.br

Conflict of interests: The authors have no conflicts of interest to declare.

Received: 08 May 2021; Revised: 07 Oct 2021; Accepted: 04 Nov 2021. 


\section{INTRODUCTION}

On December 31, 2019, the world was exposed to an unknown pneumonia-like disease in the city of Wuhan, in the province of Hubei, China. ${ }^{1}$ The etiology of this outbreak was identified as a novel coronavirus (SARS-CoV-2, an RNA virus), and the disease as the Coronavirus Disease (COVID-19). On March 11, 2020, the World Health Organization (WHO) declared the disease a pandemic in recognition of the global character of transmission of the new coronavirus. ${ }^{2}$ Until July 20, more than $14,600,000$ confirmed cases and over 450,000 deaths were registered around the globe. ${ }^{3}$

The first case in Latin America (LA) was confirmed on February 26, 2020, in Brazil. ${ }^{4}$ The dissemination of the disease was swift, reaching the last LA country to report confirmation (Haiti) on March 19, 2020.5 On May 22, during a press conference, Michael Ryan, the director of the WHO emergency program, classified South America as one of the epicenters of the pandemic. Until July 20, 2020, over 4,000,000 confirmed cases and more than 170,000 deaths were reported in the region. ${ }^{3}$

With the pandemic's progression and its spread across LA territory, the lack of resources and the disparate social inequalities in the countries that comprise it have become even more evident. According to the United Nations Development Program (UNDP)'s human development report released in December 2019, LA is the region in the world with the highest income inequality. ${ }^{6}$

In this context, considering the difficulties of these countries in combating an unprecedented pandemic, reporting reliable and detailed data is essential to guide government decision-making, develop studies and research by the academic community, and raise awareness among the general public regarding this disease. Thus, the present study aimed to evaluate the trend and dynamics of COVID-19 in LA.

\section{METHODS}

This ecological study was based on data published on the Pan American Health Organization and the World Health
Organization (PAHO/WHO) websites. ${ }^{7}$ Information was collected in three periods: 05/10/2020 (Period A), 06/19/2020 (Period B), and 07/20/2020 (Period C). The assessed variables included the number of cases of COVID-19, the number of deaths, and the adoption of preventive measures. The estimative of population was based on data published on the Economic Commission for Latin America and the Caribbean (CEPAL). ${ }^{8}$ Descriptive analysis was performed using the incidence of COVID-19 (number of new cases in each period per $10^{6}$ habitants) and its prevalence (number of cumulated cases in each period per $10^{6}$ habitants), its mortality rate (number of new deaths in each period per $10^{6}$ habitants), and its lethality (number of cumulated deaths in each period per $10^{6}$ habitants) to evaluate the tendency and dynamics of the COVID-19 pandemic in LA.

The study was conducted in accordance with the ethical standards of the responsible committee on human experimentation and with the Helsinki Declaration of 1975, as revised in 2000. However, no ethical approval was required as this article is based on public data, available in public health sites from PAHO/WHO, in according with Health Ministry of Brazil (Resolution $n^{\circ}$ 510/16). ${ }^{9}$

\section{RESULTS}

In Period A, the number of confirmed cases of COVID-19 in LA had reached 284,521, most of which were reported in Brazil (51\%), Peru (14.2\%), and Mexico (9.7\%). In a second moment (Period B), the number of cumulated cases was $1,958,180$. Brazil retained $52.8 \%$ of the confirmed cases, followed by Peru (12.7\%) and Chile (11.8\%). In Period C (07/20/2020), a total of 4,046,179 cases of COVID-19 had been notified, with Brazil leading in the first position regarding the number of confirmed cases (55\%), followed by Peru (9\%), Mexico (8.9\%), and Chile (8.4\%). The highest prevalence of COVID-19 in LA was reported in Chile, Panama, Peru, and Brazil (Table 1).

Table 1. Number of cumulated cases, deaths, and prevalence of COVID-19 in Latin America during the first wave of the pandemic, May to July 2020.

\begin{tabular}{|c|c|c|c|c|c|c|c|c|c|c|}
\hline \multirow[b]{2}{*}{ Region/Countries } & \multirow[b]{2}{*}{ Population } & \multicolumn{3}{|c|}{$\begin{array}{l}\text { Number of cumulated cases for } \\
\text { COVID-19 }\end{array}$} & \multicolumn{3}{|c|}{$\begin{array}{l}\text { Number of cumulated deaths } \\
\text { for COVID-19 }\end{array}$} & \multicolumn{3}{|c|}{$\begin{array}{c}\text { Prevalence }\left(10^{6} \mathrm{hab}\right) \text { of the } \\
\text { period }\end{array}$} \\
\hline & & May & June & July & May & June & July & A & B & $\mathrm{C}$ \\
\hline Latin America & $641,934,032$ & 284,521 & $1,958,180$ & $4,046,179$ & 15,777 & 91,777 & 173,821 & 443 & 3,050 & 6,303 \\
\hline Argentina & $45,195,777$ & 5,020 & 39,557 & 141,900 & 264 & 979 & 2,617 & 111 & 875 & 3,140 \\
\hline Bolivia & $11,673,029$ & 2,266 & 23,512 & 64,135 & 104 & 740 & 2,328 & 194 & 2,014 & 5,494 \\
\hline Brazil & $212,559,409$ & 145,328 & $1,032,913$ & $2,227,514$ & 9,897 & 48,954 & 82,771 & 684 & 4,859 & 10,479 \\
\hline Chile & $19,116,209$ & 25,972 & 231,393 & 338,759 & 294 & 4,093 & 8,838 & 1,359 & 12,105 & 17,721 \\
\hline
\end{tabular}

Note: data collected by www.paho.org/en.

Continue. 
Conclusion.

Table 1. Number of cumulated cases, deaths, and prevalence of COVID-19 in Latin America during the first wave of the pandemic, May to July 2020.

\begin{tabular}{|c|c|c|c|c|c|c|c|c|c|c|}
\hline \multirow[b]{2}{*}{ Region/Countries } & \multirow[b]{2}{*}{ Population } & \multicolumn{3}{|c|}{$\begin{array}{l}\text { Number of cumulated cases for } \\
\text { COVID-19 }\end{array}$} & \multicolumn{3}{|c|}{$\begin{array}{l}\text { Number of cumulated deaths } \\
\text { for COVID-19 }\end{array}$} & \multicolumn{3}{|c|}{$\begin{array}{c}\text { Prevalence }\left(10^{6} \mathrm{hab}\right) \text { of the } \\
\text { period }\end{array}$} \\
\hline & & May & June & July & May & June & July & A & $\mathrm{B}$ & $\mathrm{C}$ \\
\hline Latin America & $641,934,032$ & 284,521 & $1,958,180$ & $4,046,179$ & 15,777 & 91,777 & 173,821 & 443 & 3,050 & 6,303 \\
\hline Colombia & $50,882,884$ & 10,051 & 63,276 & 218,428 & 428 & 2,045 & 7,373 & 198 & 1,244 & 4,293 \\
\hline Costa Rica & $5,094,114$ & 792 & 2,058 & 12,361 & 6 & 12 & 71 & 155 & 404 & 2,427 \\
\hline Cuba & $11,326,616$ & 1,783 & 2,309 & 2,466 & 77 & 85 & 87 & 157 & 204 & 218 \\
\hline El Salvador & $6,486,201$ & 490 & 4,475 & 13,377 & 11 & 93 & 372 & 76 & 690 & 2,062 \\
\hline Ecuador & $17,643,060$ & 1,924 & 49,731 & 78,148 & 58 & 4,156 & 5,349 & 109 & 2,819 & 4,429 \\
\hline Guatemala & $17,915,567$ & 1,052 & 12,509 & 42,192 & 26 & 483 & 1,632 & 59 & 698 & 2,355 \\
\hline Haiti & $11,402,533$ & 209 & 4,688 & 7,167 & 16 & 82 & 154 & 18 & 411 & 629 \\
\hline Honduras & $9,904,608$ & 1,461 & 10,739 & 36,102 & 99 & 343 & 1,006 & 148 & 1,084 & 3,645 \\
\hline Mexico & $128,932,753$ & 27,634 & 175,202 & 362,274 & 2,704 & 20,781 & 41,190 & 214 & 1,359 & 2,810 \\
\hline Nicaragua & $6,624,554$ & 16 & 1,823 & 3,004 & 5 & 64 & 108 & 2 & 275 & 453 \\
\hline Panama & $4,314,768$ & 807 & 25,222 & 55,906 & 231 & 493 & 1,180 & 1,870 & 5,846 & 12,957 \\
\hline Paraguay & $7,132,530$ & 333 & 1336 & 4,000 & 10 & 13 & 36 & 47 & 187 & 561 \\
\hline Peru & $32,971,846$ & 40,459 & 247,925 & 366,550 & 1,124 & 7,660 & 17,455 & 1,227 & 7,519 & 11,117 \\
\hline Dominican Republic & $10,847,904$ & 10,634 & 25,068 & 57,615 & 393 & 647 & 1,006 & 980 & 2,311 & 5,311 \\
\hline Uruguay & $3,473,727$ & 694 & 853 & 1,117 & 18 & 24 & 34 & 200 & 246 & 322 \\
\hline Venezuela & $28,435,943$ & 333 & 3,591 & 13,164 & 10 & 30 & 124 & 12 & 126 & 463 \\
\hline
\end{tabular}

Note: data collected by www.paho.org/en.

Considering the incidence of the disease in Period A, Panama ( 1,870 cases $/ 10^{6}$ hab), Chile (1,359 cases $/ 10^{6}$ hab), Peru (1,227 cases $/ 10^{6}$ hab), and the Dominican Republic (980 cases $/ 10^{6}$ hab) exhibited the highest detection rates. However, in Period B, Chile (10,746 cases $/ 10^{6}$ hab), Peru (6,292 cases $/ 10^{6}$ hab), Brazil (4,176 cases/10 $10^{6}$ hab), and Panama (3,975 cases $/ 10^{6}$ hab) comprised the countries with the highest detection rates. Meanwhile, in July (Period C), the detection rate in Panama and Brazil continued to increase, whereas, in Chile $(5,616$ cases $\left./ 10^{6} \mathrm{hab}\right)$ and Peru $\left(3,598\right.$ cases $/ 10^{6}$ hab), it decreased. In contrast, Cuba, Haiti, Nicaragua, Paraguay, Uruguay, and Venezuela presented lower detection rates in all periods $(<500$ cases $\left./ 10^{6} \mathrm{hab}\right)$. This parameter increased in other countries, although in slower proportions (Figure 1).

The number of cumulated deaths in each period was 15,777 (Period A), 91,777 (Period B), and 173,821 (Period C), with Brazil being accountable for the highest number of deaths in LA due to COVID-19, corresponding to $62.6 \%, 53.3 \%$, and $47.6 \%$ in Periods A, B, and C, respectively.

The mortality rate regarding new deaths in Period A was less than 60 deaths $/ 10^{6}$ habitants in all countries. However, in the second period, Ecuador (232 deaths $/ 10^{6}$ hab), Chile (199 deaths $/ 10^{6}$ hab), Peru (198 deaths $/ 10^{6}$ hab), and Brazil (184 deaths $/ 10^{6}$ hab) presented the highest mortality rates. In Period $\mathrm{C}$, the greatest rates were reported in Peru (297 deaths $/ 10^{6}$ hab), Chile (248 deaths $/ 10^{6}$ hab), Panama (159 deaths $/ 10^{6}$ hab), and Brazil (159 deaths $/ 10^{6}$ hab). The countries that had a mortality rate of lower than 50 deaths $/ 10^{6}$ habitants in all periods were Argentina, Costa Rica, Cuba, El Salvador, Haiti, Nicaragua, Paraguay, Dominican Republic, Uruguay, and Venezuela (Figure 2).

Regarding lethality, we found that, in Period A, Nicaragua (31.3\%) and Panama (28.6\%) had the highest rates. In contrast, in Periods B and C, Mexico (11.9\% in June and $11.4 \%$ in July) and Ecuador (8.4\% in June and $6.4 \%$ in July) retained the highest values (Table 2 ).

Quarantine was adopted as a preventive measure less than 10 days after the first cases of COVID-19 were detected in El Salvador, Uruguay, Haiti, Guatemala, Venezuela, Honduras, Costa Rica, Paraguay, Colombia, and Peru. Other countries, such as Ecuador, Bolivia, Cuba, Panama, Argentina, Chile, the Dominican Republic, and Brazil, established the social isolation protocol between 11 and 20 days after the beginning of the epidemic. Mexico only implemented quarantine measures 27 days after the first confirmed case. Meanwhile, Nicaragua did not adopt the social distancing measure. 
The use of protective masks was established 30 days after the epidemic began in Venezuela, Paraguay, Uruguay, Bolivia, Peru, Cuba, Haiti, Mexico, Panama, and Colombia. Guatemala, Chile, Ecuador, Brazil, Argentina, the Dominican Republic, and Nicaragua, on the other hand, adopted this preventive measure between 31 and 49 days after the first confirmed case. El Salvador, Honduras, and Costa Rica, however, did not recommend the use of masks in the overall population.

Figure 1. Incidence of COVID-19 in Latin America during the first wave of the pandemic, May to July 2020.

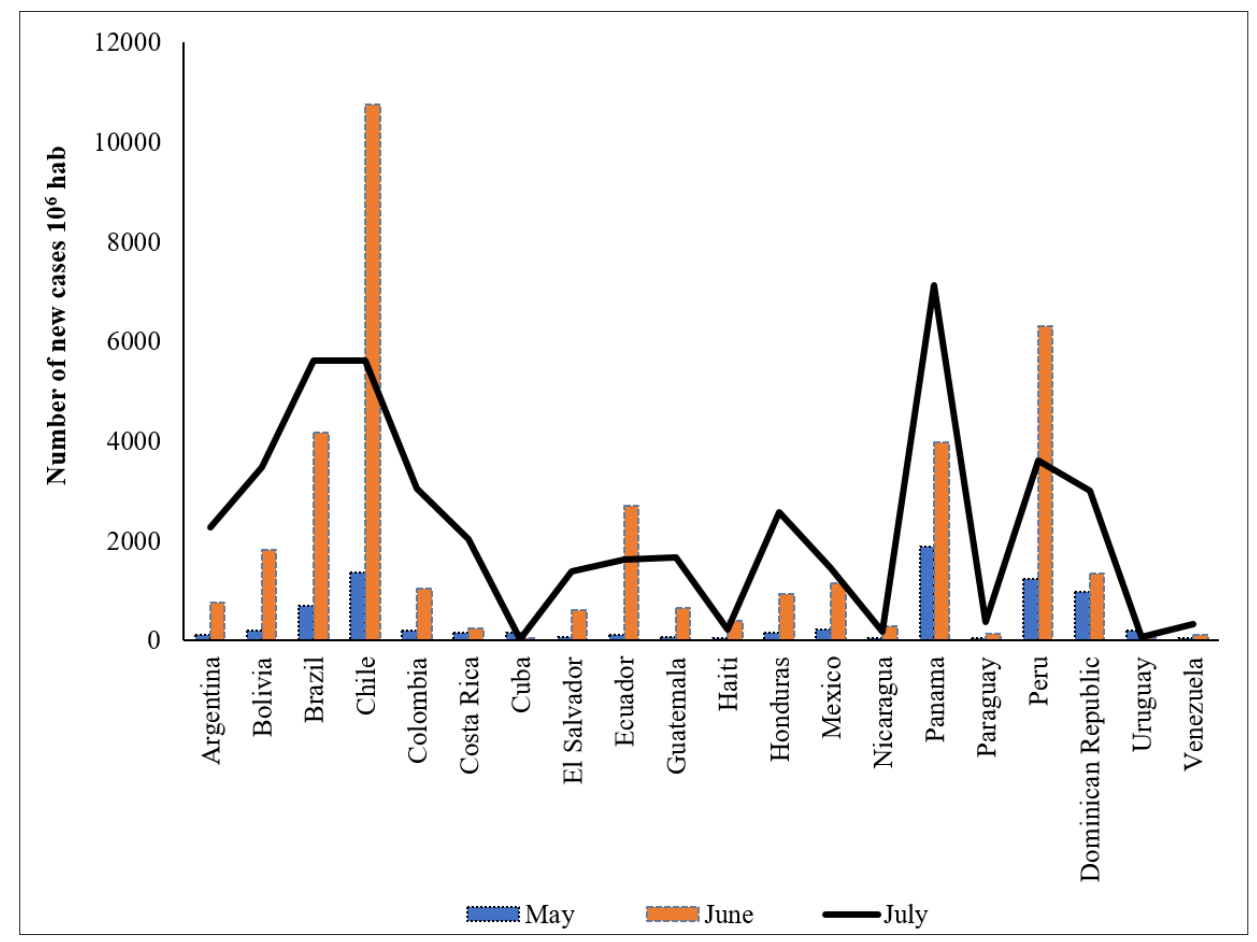

Figure 2. Mortality rate of COVID-19 in Latin America during the first wave of the pandemic, May to July 2020.

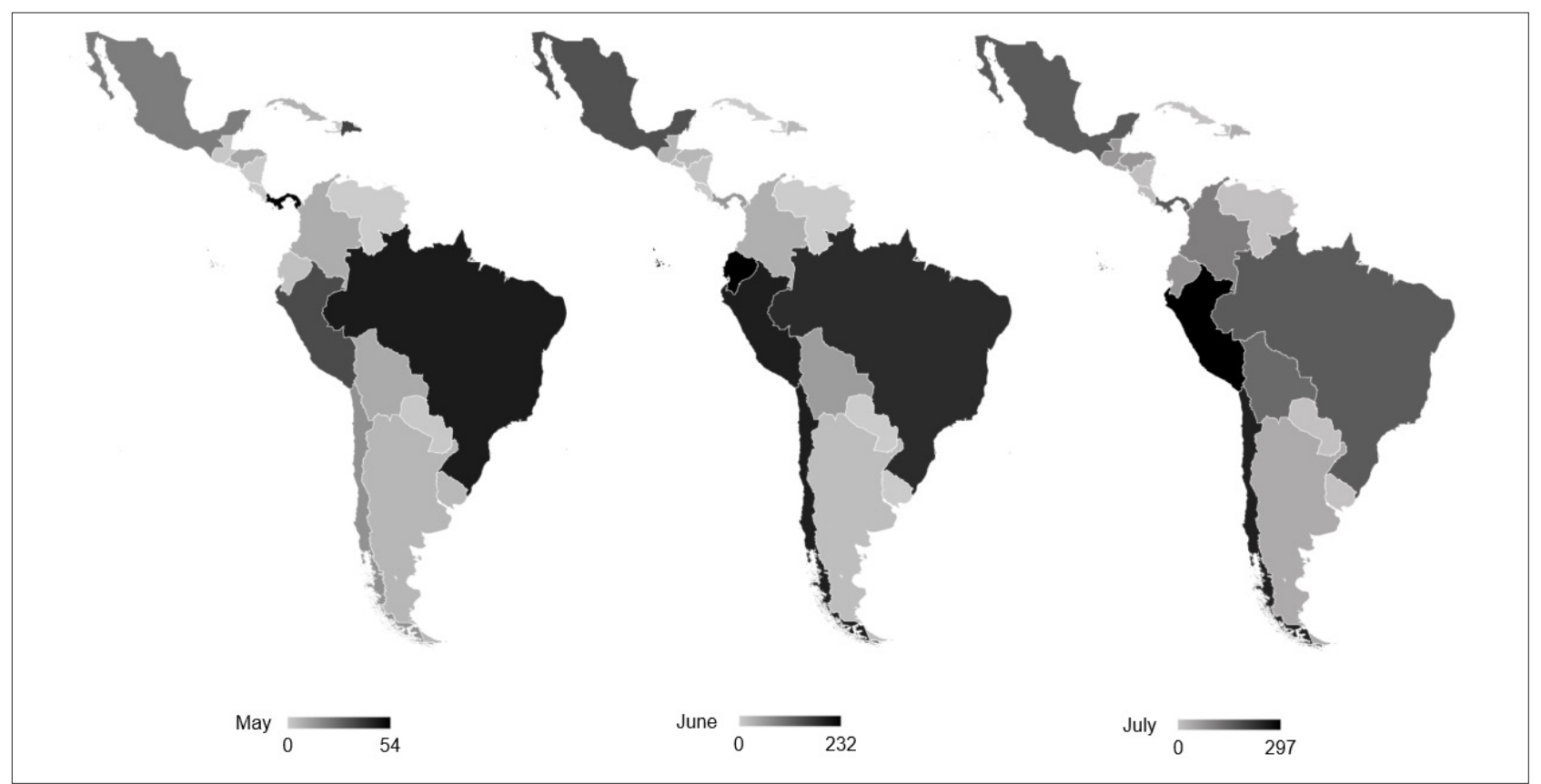


Table 2. Lethality of COVID-19 in Latin America during the first wave of the pandemic, May to July 2020.

\begin{tabular}{|c|c|c|c|c|c|c|c|c|c|}
\hline \multirow[b]{2}{*}{ Region/Countries } & \multicolumn{3}{|c|}{$\begin{array}{l}\text { Number of cases cumulated for } \\
\text { COVID-19 }\end{array}$} & \multicolumn{3}{|c|}{$\begin{array}{l}\text { Number of deaths cumulated for } \\
\text { COVID-19 }\end{array}$} & \multicolumn{3}{|c|}{ Lethality COVID-19 (\%) } \\
\hline & May & June & July & May & June & July & May & June & July \\
\hline Latin America & 284,521 & $1,958,180$ & $4,046,179$ & 15,777 & 91,777 & 173,821 & 5.5 & 4.7 & 4.3 \\
\hline Argentina & 5,020 & 39,557 & 141,900 & 264 & 979 & 2,617 & 5.3 & 2.5 & 1.8 \\
\hline Bolivia & 2,266 & 23,512 & 64,135 & 104 & 740 & 2,328 & 4.6 & 3.1 & 3.6 \\
\hline Brazil & 145,328 & $1,032,913$ & $2,227,514$ & 9,897 & 48,954 & 82,771 & 6.8 & 4.7 & 3.7 \\
\hline Chile & 25,972 & 231,393 & 338,759 & 294 & 4,093 & 8,838 & 1.1 & 1.8 & 2.6 \\
\hline Colombia & 10,051 & 63,276 & 218,428 & 428 & 2,045 & 7,373 & 4.3 & 3.2 & 3.4 \\
\hline Costa Rica & 792 & 2,058 & 12,361 & 6 & 12 & 71 & 0.8 & 0.6 & 0.6 \\
\hline Cuba & 1,783 & 2,309 & 2,466 & 77 & 85 & 87 & 4.3 & 3.7 & 3.5 \\
\hline El Salvador & 490 & 4,475 & 13,377 & 11 & 93 & 372 & 2.2 & 2.1 & 2.8 \\
\hline Ecuador & 1,924 & 49,731 & 78,148 & 58 & 4,156 & 5,349 & 3.0 & 8.4 & 6.8 \\
\hline Guatemala & 1,052 & 12,509 & 42,192 & 26 & 483 & 1,632 & 2.5 & 3.9 & 3.9 \\
\hline Haiti & 209 & 4,688 & 7,167 & 16 & 82 & 154 & 7.7 & 1.7 & 2.1 \\
\hline Honduras & 1,461 & 10,739 & 36,102 & 99 & 343 & 1,006 & 6.8 & 3.2 & 28 \\
\hline Mexico & 27,634 & 175,202 & 362,274 & 2,704 & 20,781 & 41,190 & 9.8 & 11.9 & 11.4 \\
\hline Nicaragua & 16 & 1,823 & 3,004 & 5 & 64 & 108 & 31.3 & 3.5 & 3.6 \\
\hline Panama & 807 & 25,222 & 55,906 & 231 & 493 & 1,180 & 28.6 & 2.0 & 2.1 \\
\hline Paraguay & 333 & 1,336 & 4,000 & 10 & 13 & 36 & 3.0 & 1.0 & 0.9 \\
\hline Peru & 40,459 & 247,925 & 366,550 & 1,124 & 7,660 & 17,455 & 2.8 & 3.1 & 4.8 \\
\hline Dominican Republic & 10,634 & 25,068 & 57,615 & 393 & 647 & 1,006 & 3.7 & 2.6 & 1.7 \\
\hline Uruguay & 694 & 853 & 1,117 & 18 & 24 & 34 & 2.6 & 2.8 & 3.0 \\
\hline Venezuela & 333 & 3591 & 13,164 & 10 & 30 & 124 & 3.0 & 0.8 & 0.9 \\
\hline
\end{tabular}

Note: data collected by www.paho.org/en.

\section{DISCUSSION}

After the COVID-19 epidemic reached Asia and Europe, in December 2019, the pandemic epicenter became the USA, and later Brazil in LA. Its dissemination throughout LA is mainly due to the region's significant income inequality, in addition to its poor infrastructure and limited access to public health systems, the exposure of the population to a plethora of transmissible diseases, and the lack of clean, potable water and sanitation. ${ }^{10}$ The absence of governmental response to international public health emergencies was also fundamental for the worsening of the pandemic status. Furthermore, many of the affected cities comprise large urban centers that are hubs for international trade and tourism.

Brazil, Peru, and Mexico were the three countries with the highest number of COVID-19 cases in all periods. These countries accommodate the most populous cities in LA, which are São Paulo, Lima, and Mexico City, respectively. In addition to having substantial agglomerated populations, these countries house significant indigenous populations that lack adequate social, economic, and sanitary conditions. Moreover, the Brazilian and Mexican governments have minimized the pandemic potential of COVID-19 primarily in the marginalized population, including indigenous and rural communities. ${ }^{11-13}$ Until July 6th, over 80,000 cases of COVID-19 had been notified in indigenous populations of LA, with more than 2,000 deaths. ${ }^{14}$

The lack of efficient healthcare systems has also contributed to the elevated number of COVID-19 cases in LA. Many countries have underfinanced and fragmented health systems, which limit the population's access to healthcare services. Although Brazil has an efficient public health system and considerable experience in controlling epidemics, such as arboviruses, the country continues to cope with an uncontrolled epidemic. ${ }^{13}$

In little time, Brazil quickly became the epicenter of the disease in LA with more than 2,000,000 confirmed cases of COVID-19 and more than 100,000 deaths, thus representing a risk for South America. On account of the country's continental dimensions, the pandemic in Brazil has occurred heterogeneously. Initially, the disease mainly affected large urban centers of the Brazilian Southeast, North, and Northeast. Now, the Center-West and South regions have also been affected. In addition, the process of epidemic interiorization has been taking place in many smaller cities, where the population has less access to healthcare services. ${ }^{15}$ 
The largest incidence, prevalence, and mortality rates of COVID-19 were reported in Peru, Chile, Panama, and Brazil. Initial estimates of the COVID-19 epidemic in LA suggested a high reproductive number ( $\mathrm{Rt}$ ) mainly in Ecuador (3.7-4.21), Panama (3.7-4.21), and Brazil (3.7-4.21). ${ }^{16}$ Furthermore, the prolonged course of the pandemic in Brazil and the significant mortality observed throughout indicate the probable need for renewed restrictions in the country, as suggested by Stein et al. ${ }^{17}$ interventions to contain the epidemic should have been adopted to prevent the collapse of the public health system. However, governmental political clashes have rendered tackling the pandemic even more difficult in Brazil, which, interestingly, presented distinct transmission dynamics in all regions.

Chile and Panama retain the highest Human Development Index (HDI) and income per capita in LA. Although the population of these countries has a good quality of life, they were unable to control the spread of SARS-CoV-2 infection. ${ }^{6}$ Peru underwent a drastic increase in the number of cumulated cases in Period B, reaching the second rank among the most prevalent countries; in Period C, the country exhibited the highest mortality rate in LA. International network connectivity between the largest urban centers of these countries and European, North American, and Asian destinations was essential for the arrival of the first COVID-19 cases in LA. Several cities, including Lima (Peru), Santiago (Chile), São Paulo (Brazil), and Panama City (Panama), are touristic centers, and their airports have substantial economic importance and influence on the passenger transport scenario in the world. ${ }^{18}$ Nonetheless, many countries have closed their borders to prevent the rapid spread of COVID-19, with the exception of Nicaragua, the only country that has not adopted the preventive measures recommended by the $\mathrm{PAHO} / \mathrm{WHO}$.

In Ecuador, the highest incidence of cases and deaths was registered in the second period of the study. A large number of deaths were reported in international news after the collapse of the health and mortuary systems. Unfortunately, bodies of individuals who died in this period were seen on the streets and avenues across the country. ${ }^{19}$ which accumulated more than 4,000 deaths and a high lethality rate of $8.4 \%$ in Period B. Ecuador, Chile, and Peru exhibited a peak in the disease in July.

Nicaragua, Haiti, and Venezuela had the lowest incidence, prevalence, and mortality rates in all periods. Due to their low HDI and income per capita in LA, these countries present very worrying scenarios in facing the pandemic. The inferior numbers of cases and deaths by COVID-19 may represent case underreporting, lack of testing, and difficulties in accessing the public health system..$^{5,20}$

Since 2016, Venezuela has endured a humanitarian crisis, which has resulted in insufficient surveillance and poor healthcare conditions, with minimum inputs capable of maintaining necessary and adequate hospital hygiene, as well as limited access to laboratory diagnosis. ${ }^{13,20}$
Haiti has been undergoing social chaos since its most recent natural disaster in 2010. It is known that there are less than 100 mechanical ventilators in the country and that there are only 900 health institutions available for its 11 million habitants. ${ }^{5,13}$ As a result of this situation, an increase in the number of confirmed cases and deaths was reported between Periods A and B, rendering it the 3rd country with the highest proportional increase in confirmed cases.

On account of not following the PAHO/WHO guidelines due to issues regarding the country's political regime since 2007, Nicaragua did not recommend social distancing and maintained school activities and public events. ${ }^{13}$ The country has been facing the pandemic with an evident underreporting of cases, mainly in Period A, where only 16 had been described, with a lethality rate of $31 \%$. These data are entirely flawed, given that other countries that have undergone massive testing presented a lethality rate of around 4\%; in Periods B and C, Nicaragua retained a lethality rate of $3.5 \%$. This may represent the governmental effort to combat the spread of COVID-19 in their territory more effectively.

The incidence and prevalence of the disease in Bolivia, Colombia, the Dominican Republic, Argentina, and Honduras has continued to increase, thus indicating that these countries need to receive more attention regarding coping policies and monitoring of COVID-19 spread. Interestingly, Argentina and the Dominican Republic presented low mortality rates throughout the study.

Cuba, Uruguay, and Paraguay have been effective at monitoring and combating COVID-19. Cuba has one of the lowest numbers of deaths among Latin American countries. This fact is due to the country's robust and integrated healthcare system, which widely focuses on primary care and is capable of monitoring and preventing SARS-CoV-2 infection outbreaks. ${ }^{13}$ Uruguay has a high HDI and income per capita in LA. ${ }^{6}$ Additionally, the main recommendations like quarantine and mask use for the population were early adopted.

Although Paraguay does not have an excellent HDI and income per capita, it acted quickly to contain the epidemic. One day before the WHO declared COVID-19 as a pandemic, the country adopted a national lockdown protocol, with the suspension of school activities, restriction of social events, and the establishment of a night-time curfew. In addition, the country received significant help from the population, who promptly followed the prevention protocols. The closure of land borders occurred two weeks after the country's first confirmed case.

\section{CONCLUSIONS}

The trend of COVID-19 spread in LA reveals the heterogeneous distribution and uncontrollability of the epidemic in several countries. LA's response to the pandemic depends on social, economic, political, and cultural aspects, as well as social protection and the involvement of the population with the preventive measures adopted by each government, in accordance 
with WHO recommendations. The effort has been global, with public health measures to control community transmission and reduce mortality, aiming at the social protection of vulnerable populations and frontline health workers.

\section{REFERENCES}

1. World Health Organization. COVID-19 - China [Internet]. [s.1.]: WHO; 2020. [cited 2020 June 15]. Available from: https://www. who.int/csr/don/05-january-2020-pneumonia-of-unkown-causechina/en/

2. World Health Organization. Director-General's opening remarks at the mission briefing on COVID-19 [Internet]. [s.1.]: WHO; 2020. [cited 2020 June 15]. Available from: https://www.who.int/dg/ speeches/detail/who-director-general-s-opening-remarks-at-themedia-briefing-on-covid-19---11-march-2020

3. World Health Organization. Coronavirus disease (COVID-19): situation report - 182 [Internet]. [s.l.]: WHO; 2020. [cited 2020 August 05]. Available from: https://www.who.int/docs/defaultsource/coronaviruse/situation-reports/20200720-covid-19sitrep-182.pdf?sfvrsn=60aabc5c_2

4. Rodriguez-Morales AJ, Gallego V, Escalera-Antezana JP, Méndez CA, Zambrano LI, Franco-Paredes C, et al. COVID-19 in Latin America: The implications of the first confirmed case in Brazil. Travel Med Infect Dis. 2020;35:101613.

5. Louis-Jean J, Cenat K, Sanon D, Stvil R. Coronavirus (COVID-19) in Haiti: A Call for Action. J Community Health. 2020;45(3):437-9.

6. United Nations Development Programme. Human development report 2019. [Internet]. [s.1.]: UNDP; 2019. [cited 2020 August 15]. Available from: http://www.hdr.undp.org/en/content/humandevelopment-report-2019

7. Pan American Health Organization, World Health Organization. COVID-19 Daily Update [Internet]. [s.1.]: OPAS/WHO; 2020. [cited 2020 August 04]. Available from: https://www.paho.org/en/covid19 -global-and-regional-daily-update?topic $=\mathrm{All} \& \mathrm{~d} \% 5 \mathrm{Bmin} \% 5 \mathrm{D}=\&$ $\mathrm{d} \% 5 \mathrm{Bmax} \% 5 \mathrm{D}=$ \&page $=0$

8. Comisión Económica para América Latina y el Caribe. América Latina y el Caribe: Estimaciones y proyecciones de población [Internet]. [s.1.]: CEPAL; 2019. [cited 2020 September 20]. Available from: https://www.cepal.org/es/temas/proyecciones-demograficas/ estimaciones-proyecciones-poblacion-total-urbana-ruraleconomicamente-activa

9. Ministério da Saúde. Conselho Nacional de Saúde. Resolução $\mathrm{N}^{\circ}$ 510/2016 [Internet]. Brasília: 2016. [cited 2021 June 10]. Available from: https://bvsms.saude.gov.br/bvs/saudelegis/cns/2016/ res0510_07_04_2016.html

\section{CONFLICT OF INTEREST}

The authors declare that they have no conflict of interests.

10. Comisión Económica para América Latina y el Caribe. Informe COVID-19 CEPAL - OPS [Internet]. [s.1.]: CEPAL; 2020. [cited 2020 October 14]. Available from: https://www.cepal.org/es/ publicaciones/45840-salud-economia-convergencia-necesariaenfrentar-covid-19-retomar-la-senda

11. Ibarra-Nava I, Cárdenas-De La Garza JA, Ruiz-Lozano RE, Salazar-Montalvo RG. Mexico and the COVID-19 Response. Disaster Med Public Health Prep. 2020;14(4):e17-e18.

12. Meneses-Navarro S, Freyermuth-Enciso MG, PelcastreVillafuerte BE, Campos-Navarro R, Meléndez-Navarro DM, GómezFlores-Ramos L. The challenges facing indigenous communities in Latin America as they confront the COVID-19 pandemic. Int J Equity Health. 2020;19(1):63.

13. Burki T. COVID-19 in Latin America. Lancet Infect Dis. 2020;20(5):547-8.

14. Fundação Oswaldo Cruz (FIOCRUZ). Panorama da resposta global à COVID-19 - Informe 14. [Internet]. Rio de Janeiro (RJ): 2020. [cited 2020 October 14].Available from: https://portal.fiocruz. $\mathrm{br} /$ sites/portal.fiocruz.br/files/documentos/panorama_resposta_ global_covid19_14.pdf

15. Lobo A de P, Cardoso-dos-Santos AC, Rocha MS, Pinheiro RS, Bremm JM, Macário EM, et al. COVID-19 epidemic in Brazil: Where are we at? Int J Infect Dis. 2020;97:382-5.

16. Caicedo-Ochoa Y, Rebellón-Sánchez DE, Peñaloza-Rallón M, Cortés-Motta HF, Méndez-Fandiño YR. Effective Reproductive Number estimation for initial stage of COVID-19 pandemic in Latin American Countries. Int J Infect Dis. 2020;95:316-8.

17. Stein C, Cousin E, Malta DC, Ribeiro ALP, Machado ÍE, Vasconcelos AMN, et al. COVID-19 Pandemic in Brazil: Institute for Health Metrics and Evaluation Projections and the Ensuing Evolution. Epidemiol Serv Saúde. 2021;30(1):e2020680.

18. Dias MO, Pessanha MT. Air passenger transportation in Latin America. Glob Sci Journals. 2019;7(11):144-53.

19. Torres I, Sacoto F. Localising an asset-based COVID-19 response in Ecuador. Lancet. 2020;395(10233):P1339.

20. Carrillo-Larco RM. COVID-19 data sources in Latin America and the Caribbean. Travel Med Infect Dis. 2020;38:101750.

\section{How to cite:}

Cézar RC, Lira ML, Nogueira MG, Freitas BA, Damasceno LS. Trend and dynamics of the COVID-19 pandemic in Latin America during the first wave. Rev Med UFC. 2022;62(1):1-7. 